\title{
On the identity of Blanco's Cissus frutescens and its correct name in Melicope (Rutaceae) with neotypification of Cissus arborea Blanco
}

\author{
Marc S. Appelhans ${ }^{1,2}$, Jun Wen² \\ I Department of Systematic Botany, Albrecht-von-Haller Institute of Plant Sciences, University of Göttingen, \\ Untere Karspüle 2, 37073 Göttingen, Germany 2 Department of Botany, Smithsonian Institution, PO Box \\ 37012, Washington, DC 20013-7012, USA
}

Corresponding author: Marc S. Appelhans (Marc.Appelhans@biologie.uni-goettingen.de)

Academic editor:P. Acevedo-Rodríguez | Received 6August 2015 | Accepted 8 December 2015 | Published 12 January 2016

Citation: Appelhans MS, Wen J (2016) On the identity of Blanco's Cissus frutescens and its correct name in Melicope (Rutaceae) with neotypification of Cissus arborea Blanco. PhytoKeys 58: 81-85. doi: 10.3897/phytokeys.58.5847

\begin{abstract}
The names Cissus frutescens and C. arborea have a long history of confusion. Cissus frutescens Blanco belongs to the genus Melicope (Rutaceae) and we herein correct a nomenclatural mistake made by T.G. Hartley in the revision of Melicope. The name Melicope confusa (Merr.) P.S. Liu was accepted for this taxon by Hartley. However, Cissus frutescens Blanco represents the earliest name for this entity and a new combination, Melicope frutescens (Blanco) Appelhans \& J.Wen is herein proposed. Neotypification of Cissus arborea Blanco is also provided.
\end{abstract}

\section{Keywords}

Blanco, Cissus, Melicope confusa, Melicope frutescens, Nomenclature, Philippines, Rutaceae, Vitaceae

\section{Introduction}

The name Cissus frutescens Blanco was published in 1837 in the first edition of Francisco Manuel Blanco's Flora de Filipinas (Blanco 1837). The description in Spanish was relatively short and did not cite any collection. Blanco's second edition of this work was published in 1845 shortly after his death and included several name changes without comments or reference to the first edition (Merrill 1905). Among these names 
is Cissus frutescens, which was changed to Cissus arborea Blanco, but the treatment of the taxon remained identical to that in the first edition (Blanco 1845).

After Blanco's death, an addendum to the Flora de Filipinas was written by Fernandez-Villar, who considered Cissus frutescens/C. arborea conspecific with Evodia roxburghiana (Cham.) Benth. [Evodia $=$ Euodia $^{1}$, Rutaceae] (Fernandez-Villar, 18771883). Euodia roxburghiana is currently known as Melicope lunu-ankenda (Gaertn.) T.G.Hartley, and interestingly, only a single specimen of this widespread species was cited from the Philippines in the latest revision of Melicope and Euodia (Hartley, 2001), suggesting that it might be rare in the Philippines. This was highlighted by Merrill, who stated that the species was "not definitely known from the Philippines" (Merrill 1918: 198).

In 1918 Merrill also treated Cissus frutescens/C. arborea as conspecific with E. glabra Blume, noting that "Blanco's descriptions were very indefinite, and the species Blanco described might with equal propriety be reduced to almost any trifoliolate species of Evodia with glabrous leaves" (Merrill 1918: 198). In 1918, Merrill mentioned a collection of Cissus frutescens that he collected in the vicinity of Blanco's locality for this species (Merrill, Species Blancoanae No. 904, Fig. 1). Merrill considered this collection an "illustrative specimen" with duplicates deposited at A, GH, K, L, NSW, NY, P, US and W. In 1922, Merrill published the new species Euodia confusa Merr. where Merrill 904 was listed along with many other specimens. Liu (1962) transferred Euodia confusa to Melicope, a decision which is in agreement with recent revisionary (Hartley and Stone 1989; Hartley 2001) and molecular phylogenetic studies (Appelhans et al. 2014a, b) where a total of seven species, restricted to New Guinea, northern Australia and several Pacific island groups are recognized in Euodia. All species of Euodia from the Philippines have been transferred to Melicope (Hartley and Stone 1989; Hartley 2001).

The latest revision of Melicope (Hartley 2001) included the lectotypification and the neotypification of the names Melicope confusa and Cissus frutescens, respectively. Hartley (2001) reported that the type of Euodia confusa (Ramos 15055, PNH) was lost and therefore he chose Borden 3045 (NY) among the paratypes, as its lectotype. $\mathrm{He}$ also designated Merrill 904 as the neotype of Cissus frutescens, which he placed as a synonym of Melicope confusa (Hartley 2001). Merrill 904 is the "illustrative specimen" that Merrill provided for Blanco's names and which was listed in the protologue of Euodia confusa (Merrill 1922).

Until the neotypification of Cissus frutescens (Hartley 2001), the status of Blanco's names was unclear. Blanco's species descriptions were not detailed enough to differentiate among several species of Euodial Melicope, and his collections were lost. However, by assigning a neotype to Cissus frutescens, Hartley (2001) definitely associated the specimen Merrill 904 to this taxon name. By the principle of nomenclatural priority the species epithet frutescens must be used for the entity of Melicope confusa, as M. confusa represents a synonym of Cissus frutescens. The epithet frutescens is not pre-empted in Melicope.

Fernandez-Villar used the old spelling Evodia, whereas the conserved spelling is Euodia 


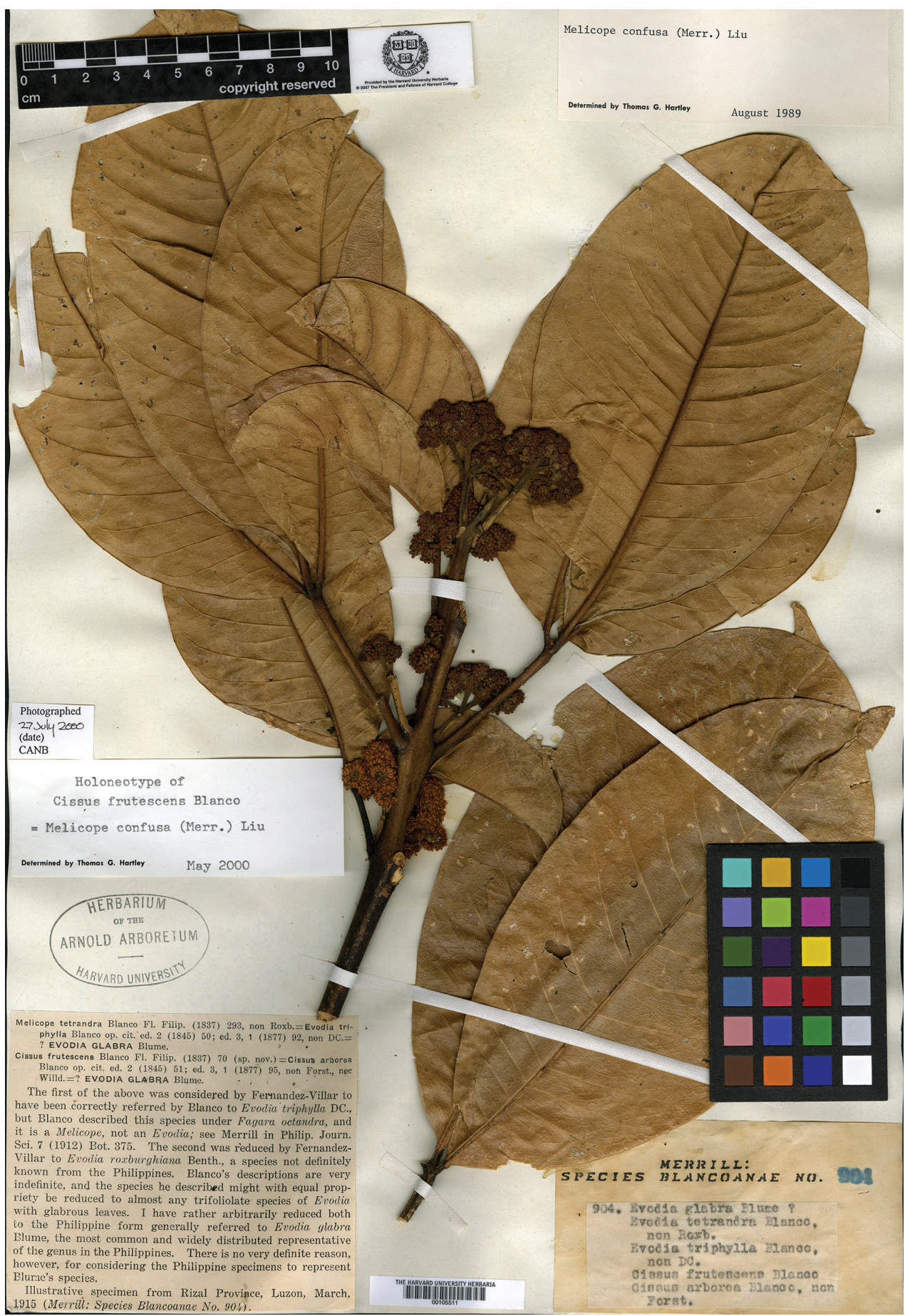

Figure I. The neotype of Melicope frutescens (Blanco) Appelhans \& J.Wen (A). 
Three other authors used the name Cissus arborea. Cissus arborea Forssk. (Forsskål 1775) is a synonym of Salvadora persica L. (Salvadoraceae; Roemer and Schultes 1818); C. arborea Willd. ex Roem. \& Schult. is a synonym of Ardisia guianensis (Aubl.) Mez. (Mez 1901); and C. arborea (L.) Des Moul. is a synonym of Nekemias arborea (L.) J.Wen \& Boggan (Wen et al. 2014), so the Des Moulins' taxon remains the only Cissus arborea that actually represents a Vitaceae species.

\section{Taxonomic treatment}

Melicope frutescens (Blanco) Appelhans \& J.Wen, comb. nov. urn:Isid:ipni.org:names:77151881-1

Basionym. Cissus frutescens Blanco, Flora de Filipinas, ed. 1: 70. 1837. Type: Philippines. Luzon: Rizal, Mar 1915, Merrill: Species Blancoanae No. 904 (neotype: A!, designated by Hartley 2001, p. 220; isoneotypes: GH!, K, L, NSW, NY!, P!, US!, W).

Cissus arborea Blanco, nom. illeg., Flora de Filipinas, ed. 2: 51.1845 (non Forssk., 1775). Type: Philippines. Luzon: Rizal, Mar 1915, Merrill: Species Blancoanae No. 904 (neotype: A!, designated here; isoneotypes: GH!, K, L, NSW, NY!, P!, US!, W).

Euodia confusa Merr., Philipp. J. Sci. 20: 391. 1922. Melicope confusa (Merr.) P.S. Liu, III. Native Introd. Lign. Pl. Taiwan 2: 876. 1962. Type: Philippines. Luzon: Bataan, Borden FB 3045 (lectotype: NY!, designated by Hartley, 2001, p. 220; isolectotypes: BO, SING, US!).

In addition to its distribution in the Philippines, Melicope frutescens is known to occur in Borneo, Sulawesi and the Moluccas. It typically grows in the lowlands but reached elevations of up to $1800 \mathrm{~m}$ in the Philippines. The species occurs in primary, secondary, and disturbed rainforests.

\section{Acknowledgements}

We thank Sue Lutz for her assistance with obtaining relevant publications, the curators of A for providing a high-resolution image of the specimen Merrill 904, Warren Wagner, Larry Dorr and John Boggan for their suggestions, and Pedro Acevedo for his detailed edits of the manuscript. We acknowledge support by the Open Access Publication Funds of Göttingen University.

\section{References}

Appelhans MS, Wen J, Wagner WL (2014a) A molecular phylogeny of Acronychia, Euodia, Melicope and relatives (Rutaceae) reveals polyphyletic genera and key innovations 
for species richness. Molecular Phylogenetics and Evolution 79: 54-68. doi: 10.1016/j. ympev.2014.06.014

Appelhans MS, Wen J, Wood KR, Allan GJ, Zimmer EA, Wagner WL (2014b) Molecular phylogenetic analysis of Hawaiian Rutaceae (Melicope, Platydesma and Zanthoxylum) and their different colonisation patterns. Botanical Journal of the Linnean Society 174: 425-448. doi: 10.1111/boj.12123

Blanco FM (1837) Flora de Filipinas: segun el sistema sexual de Linneo, ed. 1. Imprenta de Sto. Thomas, 887 pp.

Blanco FM (1845) Flora de Filipinas: segun el sistema sexual de Linneo, ed. 2. D. Miguel Sanchez, 619 pp.

Forsskål P (1775) Flora Aegyptiaco-Arabica. Ex Officina Mölleri, Hauniæ [Copenhagen], 1-32. doi: 10.5962/bhl.title.41

Fernandez-Villar C (1877-1883) Novissima appendix ad floram Philippinarum R. P. Fr. Emmanuelis Blanco. Plana, Manila, 375 pp.

Hartley TG, Stone BC (1989) Reduction of Pelea with new combinations in Melicope (Rutaceae). Taxon 38: 119-123. doi: 10.2307/1220910

Hartley TG (2001) On the taxonomy and biogeography of Euodia and Melicope (Rutaceae). Allertonia 8: 1-328.

Liu PS (1962) Illustrations of Native and Introduced Ligneous Plants of Taiwan, vol. 2. College of Agriculture, National Taiwan University, Taipei, Taiwan, 686 pp.

Merrill ED (1905) A review of the identifications of the species described in Blanco's Flora de Filipinas. Bureau of Public Printing, Manila, 132 pp. doi: 10.5962/bhl.title.58554

Merrill ED (1918) Species Blancoanae. A critical revision of the Philippine species of plants described by Blanco and by Llanos. Bureau of Public Printing, Manila, 423 pp. doi: 10.5962/ bhl.title.2116

Merrill ED (1922) New or noteworthy Philippine plants XVII. Philippine Journal of Science 20: $367-476$.

Mez C (1901) IX. Myrsinaceae. In: Urban I (Ed.) Symbolae Antillanae seu fundamenta Florae Indinae Occidentalis, Vol. 2. Borntraeger, Lipsiae [Leipzig], 389-433.

Roemer JJ, Schultes JA (1818) Caroli a Linné. Systema vegetabilium: secundum classes, ordines, genera, species. Cum characteribus, differentiis et synonymiis, vol. 3. Sumtibus J.G. Cottae, Stuttgart, 888 pp.

Wen J, Boggan J, Nie Z-L (2014) Synopsis of Nekemias Raf., a segregate genus from Ampelopsis Michx. (Vitaceae) disjunct between eastern/southeastern Asia and eastern North America, with ten new combinations. PhytoKeys 42: 11-19. doi: 10.3897/phytokeys.42.7704 